\title{
Liberal Democracy in Question?
}

\author{
Jeffrey C. Isaac
}

$\Lambda$ specter is haunting world politics: the specter of "illiberal democracy."

The project of instituting a new form of illiberal democracy in place of the supposedly outmoded form of liberal democracy is most closely linked to Hungarian Prime Minister Viktor Orban, who has repeatedly announced this intention. But the idea is commonly associated with a broader range of political leaders, from Jaroslaw Kaczyński in Poland, Recep Tayyip Erdogan in Turkey, and Vladimir Putin in Russia to Marine LePen in France, Boris Johnson and Nigel Farange in the UK, and Donald Trump in the United States. Such leaders claim the mantle of democratic legitimacy. They seek and obtain power through elections, profess to represent the "nation" against cosmopolitan and liberal elites, and embrace a harsh majoritarianism that is hostile to countervailing forces-independent judiciaries, independent media institutions, human rights and activist NGOs - that might limit their political projects. In the first instance this phenomenon is ideological and party-political, and relates to the ways that such actors seek to use governmental power to reshape domestic political institutions in an "illiberal" or even anti-liberal way, repudiating long-standing features of liberal democratic systems (Some of these features are discussed below in Bernard Yack's "Political Liberalism: Political, Not Philosophical"). But it is also a global and transnational phenomenon, because these developments are actively promoted or opposed by the foreign policies of global powers like the U.S., Russia, and China; because there are transnational diffusion processes and broader dynamics of globalization behind them; and because the fate of the European Union, and of "Europe," looms large behind these developments.

Central to many of these issues is the political fate of Turkey, a country at the border of Europe and the Middle East and North Africa; a member of NATO and a candidate for membership in the EU; a country on the front lines of overlapping global crises associated with ISIS-related violence in Syria, Iraq, and Libya and an epic flow of refugees; and a "new democracy" viewed by some as a model of "Islamist moderation" that is on the verge of falling into a new form of authoritarianism if it has not already done so. Turkey indeed figures in three of this issue's four research articles, and furnishes a lens through which to view all four of them.
Francisco Gutiérrez-Sanín and Elisabeth Jean Wood's "What Should We Mean by 'Pattern of Political Violence'? Repertoire, Targeting, Frequency, and Technique" is a contribution to a burgeoning literature on the comparative politics of violence. In it, the authors "provide a new conceptualization of political violence, defining an organization's pattern of violence as the configuration of repertoire, targeting, frequency, and technique in which it regularly engages. This approach adds precision to the documentation and analysis of political violence, clarifies the evaluation of rival theories, and opens up new research questions." While they develop this conceptualization via an analysis of violence by insurgent and paramilitary non-state organizations against civilians in Colombia, their approach would seem relevant to any situation where violence is being organized for political purposes, whether by insurgent or paramilitary organizations, groups with state-like aspirations-such as ISIS, which they discuss - or even states themselves.

It is a commonplace of political science that wherever there are states there are "patterns" and "repertoires" of violence. Even in liberal democratic states violence is organized and deployed to enforce "criminal justice" (see our September 2015 special issue on The Political Science of Policing and Incarceration), to "maintain public order," and at times to limit dissent and political protest (e.g., the violence recently deployed against protestors at Standing Rock by sheriffs and local police- agents of the state- that was featured on the cover of our December 2016 issue). At the same time, the processes of liberal democratization are widely believed to constrain and minimize such political violence, by instituting relatively fair, open, and legitimate forms of civil association and political organization and a system of regular, peaceful competition for and rotation of office. Such measures, if they succeed, can incorporate aggrieved groups into the political process and "domesticate" their grievances.

Stephen Brooke's "From Medicine to Mobilization: Social Service Provision and the Islamist Reputational Advantage" addresses an aspect of such political incorporation via the case of the Egyptian Muslim Brotherhood. The Brotherhood is perhaps the most important Islamic social and political movement in the world. Through its mobilizational power and its political party, the Freedom 
and Justice Party, it played a central role in the uprisings of 2011. As Brooke writes: "From 2011 to 2013 the Muslim Brotherhood dominated politics, winning elections for parliamentary seats and presidential office, and mustering the popular support to push through constitutional referendums. In July of 2013 Egypt's military dislodged the Brotherhood and seized control of the country, inaugurating a sweeping campaign of state violence. In addition to mass killings and widespread torture and imprisonment, the regime has also shuttered and seized thousands of the Brotherhood's social institutions in an attempt to strip the group of the mechanisms which, for decades, served to connect them with average Egyptians." In his article, Brooke employs a mixed-method approach to analyze the role of the Muslim Brotherhood's provision of high-quality medical services in establishing its political reputation and political linkages with voters. He finds that "Respondents exposed to factual information about the Brotherhood's medical provision are significantly more likely to consider voting for the Brotherhood in elections," and argues more generally that "professional and businesslike social-service provision-rather than ideological indoctrination or lockstep organizational discipline-generates powerful reputation-based linkages with voters."

Brooke makes clear that while his study centers on Egypt's Brotherhood, the issues raised relate to a wide range of cases-Indonesia, Lebanon, Yemen, and Turkey-where party-based social movements, especially Islamist ones, employ social service provision as a means of building political support. In the Egyptian case, political success generated a crisis that led to repression of the movement by the military. In the Turkish case, the political successes of the Justice and Development Party-formed by Erdogan in 2001 and modeled on the Muslim Brotherhood-led to a somewhat different result: the growing authoritarianism of President Erdogan, leading to strong political opposition, a mass protest movement symbolized by the Gezi Park protests of 2013, and the repression of the opposition by a more emboldened authoritarian regime.

S. Erdem Aytaç, Luis Schiumerini, and Susan Stokes's "Protest and Repression in New Democracies" centers on these dynamics of mobilization and repression in regimes in the process of some measure of (perhaps halting and fragile) democratization. (See also this issue's critical dialogue between Emily Beaulieu, author of Electoral Protest and Democracy in the Developing World, and John Medearis, author of Why Democracy Is Oppositional.) As they write: "Elected governments sometimes deal with protests by authorizing the police to use less-lethal tools of repression: water cannons, tear gas, rubber bullets, and the like. When these tactics fail to end protests and instead spark larger, backlash movements, some governments reduce the level of violence but others increase it, causing widespread injuries and loss of life." Their article seeks to explain the variation in governmental response to protest, by analyzing "three recent cases of governments in new democracies facing backlash movements" - the Turkish government's response to the Gezi Park demonstrations that began in Istanbul in late May, 2013; the Brazilian government's response to protests that began in São Paulo in early June, 2013; and the Ukrainian government's response to the EuroMaidan protests that began in Kiev in late November 2013 and lasted until February, 2014. In each case protest was initially met with a measure of repression. But while in Brazil and Ukraine the governments pulled back the police and offered some concessions to protestors, in Turkey the Erdogan government allowed violence to escalate, refusing to make concessions and "upping the level of repression to very high levels, resulting in several deaths and dozens of injuries." Aytaç, Schiumerini, and Stokes argue that the explanation for this variation can be sought in the political power, and self-confidence, of the government in question, and that "elected governments that rest on very stable bases of support" — such as Erdogan's in Turkey_ "may be tempted to deploy tactics more commonly associated with authoritarian politics."

Such authoritarian moves are matters of "domestic" politics taken by the leaders of particular nation-states. But they are also transnational and international matters. They often involve the demonization, regulation, or repression of international NGOs. They are often justified as responses to domestic or international "terrorism." They often involve "taking sides" in global ideological disputes (about "Islam" or "the West" or "Eurasianism" or "democracy") and they always involve questions of international law and global governance. Jennifer Dixon's "Rhetorical Adaptation and Resistance to International Norms" addresses precisely such questions, by analyzing how states accused of violating international human rights laws and norms deal with these accusations on the world stage, and especially discussing how state elites employ rhetorical strategies that involve apparent compliance with international norms while continuing to violate them. She advances this account through a "plausibility probe" of a particularly illuminating example of "rhetorical adaptation" in the service of avoidance-Turkey's post-World War II narrative of the Armenian Genocide. Dixon traces the evolution of official policy regarding public education and public commemoration of the genocide and especially regarding whether it can be publicly acknowledged as a genocide. Her rich account makes clear that the politics of historical memory is important both to international governance and to the domestic politics of nationalism. The Turkish failure to come to terms with the 1915 genocide is linked to other illiberal regime commitments, from the repression of expressions of Kurdish national identity to a broadly hostile approach to political dissent and political opposition. 
Such a posture is not unique to "new democracies" inclined toward an "illiberal" turn to authoritarianism. One case in point is the U.S. itself. Our September 2015 issue featured similar themes, all centered on the U.S. experience. Georgia Warnke's "Philosophical Hermeneutics and the Politics of Memory," Lawrie Balfour's "Ida B. Wells and 'Color Line Justice,"” and Desmond Jagmohan's "Slavery and the Making of American Capitalism" all centered on the enduring legacies of slavery and Jim Crow, and the failure of American political culture to reckon with these legacies. And Christopher J. Coyne's "The Militarization of U.S. Policing and the Future of American Politics," William Smith's "Policing Democracy: Race, Riots, and Protest," Alexander Gourevitch's "Police Work," and Lynda G. Dodd's "The Rights Revolution in the Age of Obama and Ferguson" all dealt with the deployment of violence by the U.S. state, and with similar dynamics of violence, backlash, and response discussed by Aytaç, Schiumerini, and Stokes with regard to Brazil, Turkey, and Ukraine.

These dynamics were not far from the rhetorical surface of the exceptionally heated 2016 U.S. Presidential election contest. Donald Trump's winning campaign message_ "Make America Great Again"-centered on tapping and mobilizing fear and promising a hardline response to the purported dangers. Whether the question was ISIS ("We're going to kick the ass of ISIS"), fears of terrorism in "the homeland" ("a total and complete shutdown of Muslims entering the United States"), fears of undocumented immigrants ("They're bringing drugs. They're bringing crime. They're rapists"), or outrage at Black Lives Matter ("They certainly have ignited people and you see that ... It's a very, very serious situation and we just can't let it happen"), Trump stood for, and stands for, the forceful repudiation of liberalism, represented as too "soft," in favor of something much more decisive and much more nationalist.

Why did Trump win? What constituencies did he most effectively activate? What are likely to be his policies, and what are likely to be the consequences of these policies? These are enormous questions, and political scientists will no doubt be engaging and debating them for years to come. At the same time, it is beyond doubt that the phenomenon of Trump is part of the broader phenomenon of the rise of populist leaders playing on public insecurity and fear, and promising to "protect" and "restore the nation" by moving liberal democracy in an illiberal direction. While this issue contains no articles on U.S. politics, the Review section contains discussion of some very important books that center on what might be called the mobilization of "irrationalism." Our symposium on Christopher Achen and Larry Bartels' Democracy For Realists: Why Elections Do Not Produce Responsive Government, includes commentaries by a range of Americanists, comparativists, and theorists: Elizabeth Cohen, Isabela
Mares, Neil Roberts, Andrew Sabl, Antje Schwennicke, and Gerald Wright. David O. Sears' review essay, "An Ignorant and Easily Duped Electorate?" discusses Jennifer Hochschild and Katherine Einstein's Do Facts Matter?: Information and Misinformation in American Politics, Arthur Lupia's, Uninformed: Why People Seem to Know So Little about Politics and What We Can Do about It and Efren O. Perez's Unspoken Politics: Implicit Attitudes and Political Thinking. And one of our Critical Dialogues places Kyle Mattes and David Redlawsk's The Positive Case For Negative Campaigning into conversation with Diana Mutz's In-Your-Face Politics: The Consequences of Uncivil Media.

This issue also contains discussions that perhaps point in a more hopeful direction. Carmen Sirianni's review essay, "Civic Innovation: Yesterday, Today, and Tomorrow," discusses three books that consider alternatives to a politics of alienation and fear: Hollie Russon Gilman's Democracy Reinvented: Participatory Budgeting and Civic Innovation in America, Susan Moffitt's Making Public Policy: Participatory Bureaucracy in American Democracy, and Beth Simone Noveck's Smart Citizens, Smarter State: The Technology and the Future of Governing. And two Critical Dialogues address the importance of social movements in invigorating liberal democratic politics: Michael D. Heaney and Fabio Rojas' Party in the Street: The Antiwar Movement and the Democratic Party after $9 / 11$ is in dialogue with Daniel Schlozman's When Movements Anchor Parties: Electoral Alignments in American History, and Deva R. Woodly's The Politics of Common Sense: How Social Movements Use Public Discourse to Change Politics and Win Acceptance is in dialogue with Charles T. Lee's Ingenious Citizenship: Recrafting Democracy for Social Change.

Liberal democratic politics would appear to be at a crossroads, in the United States, in Europe, and those other places where it has seemed to flourish or at least to emerge. If in 1989 it was possible for many to talk seriously about "the end of history," there can be no doubt that this supposed "end of history" is now ended. Political science, in all of its pluralism of methodological, theoretical, and ethical perspectives will be challenged to engage and to explain the trials currently facing liberal democracy and the possible paths forward. Meeting the challenge will not be easy. As Timothy V. Kaufman-Osborn suggests in his "Disenchanted Professionals: The Politics of Faculty Governance in the Neoliberal Academy," the conditions under which we work, and the emerging structures of knowledge production and dissemination, present serious challenges of their own to "the liberal arts" and to the very idea that university-based scholarship and teaching can be agencies of public enlightenment and civic education. At the same time, political scientists, and university-based scholars and teachers more generally, have faced similar challenges before. If one job of scholarly journals such as 
ours is simply to publish the very best research and writing, come what may, a second is to nurture the conditions, and the intellectual passions, that will promote further research and writing. This involves the deliberate cultivation of a kind of hopefulness about inquiry itself.

And so I end this Introduction where this issue of Perspectives actually begins, with the 2016 APSA Presidential Address of Jennifer Hochschild. "Left Pessimism and Political Science" is a provocative piece. It is a provocation of hopefulness about the possibilities of political science. It seems especially fitting that its author is the founding editor of this journal. To paraphrase the oft-quoted Antonio Gramsci, I am not sure whether Jennifer is criticizing a "pessimism of the will" or a "pessimism of the intellect." I personally think that her piece is usefully read against the much more pessimistic account of Timothy-Kaufman-Osborne, and in light of the question that heads this very Introduction - the question of liberal democracy's future itself. At the same time, I am certain that the message of her piece echoes the hopefulness of this journal itself as “A Political Science Public Sphere." Jennifer's Presidential Address is the last one that will be published in this journal under my editorship. I am very happy to publish it. Because everything that we have done with this journal over the past decade and more has been possible only because of her work to create the journal. I share her hopefulness that political science can continue to improve as an agency of public enlightenment and public education. 


\section{Statement of Mission and Procedures}

Perspectives on Politics seeks to provide a space for broad and synthetic discussion within the political science profession and between the profession and the broader scholarly and reading publics. Such discussion necessarily draws on and contributes to the scholarship published in the more specialized journals that dominate our discipline. At the same time, Perspectives seeks to promote a complementary form of broad public discussion and synergistic understanding within the profession that isessential toadvancing scholarship and promoting academic community.

Perspectives seeks to nurture a political science public sphere, publicizing important scholarly topics, ideas, and innovations, linking scholarly authors and readers, and promoting broad reflexive discussion among political scientists about the work that we do and why this work matters.

Perspectives publishes work in a number of formats that mirror the ways that political scientists actually write:

Research articles: As a top-tier journal of political science, Perspectives accepts scholarly research article submissions and publishes the very best submissions that make it through our double-blind system of peer review and revision. The only thing that differentiates Perspectives research articles from other peer-reviewed articles at top journals is that we focus our attention only on work that in some way bridges subfield and methodological divides, and tries to address a broad readership of political scientists about matters of consequence. This typically means that the excellent articles we publish have been extensively revised in sustained dialogue with the editor-me-to address not simply questions of scholarship but questions of intellectual breadth and readability.

"Reflections" are more reflexive, provocative, or programmatic essays that address important political science questions in interesting ways but are not necessarily as systematic and focused as research articles. These essays often originate as research article submissions, though sometimes they derive from proposals developed in consultation with the editor in chief. Unlike research articles, these essays are not evaluated according to a strict, doubleblind peer review process. But they are typically vetted informally with editorial board members or other colleagues, and they are always subjected to critical assessment and careful line-editing by the editor and editorial staff.

Scholarly symposia, critical book dialogues, book review essays, and conventional book reviews are developed and commissioned by the editor in chief, based on authorial queries and ideas, editorial board suggestions, and staff conversations.

Everything published in Perspectives is carefully vetted and edited. Given our distinctive mission, we work hard to use our range of formats to organize interesting conversations about important issues and events, and to call attention to certain broad themes beyond our profession's normal subfield categories.

For further details on writing formats and submission guidelines, see our website at http://www.apsanet.org/ perspectives/ 